\title{
Modelling the socio-economic impacts of modern bioenergy in rural communities in
} Ghana

\author{
Kemausuor, Francis; Bolwig, Simon; Miller, Shelie
}

Published in:

Sustainable Energy Technologies and Assessments

Link to article, DOI:

10.1016/j.seta.2016.01.007

Publication date:

2016

Document Version

Peer reviewed version

Link back to DTU Orbit

Citation (APA):

Kemausuor, F., Bolwig, S., \& Miller, S. (2016). Modelling the socio-economic impacts of modern bioenergy in rural communities in Ghana. Sustainable Energy Technologies and Assessments, 14, 9-20. https://doi.org/10.1016/j.seta.2016.01.007

\section{General rights}

Copyright and moral rights for the publications made accessible in the public portal are retained by the authors and/or other copyright owners and it is a condition of accessing publications that users recognise and abide by the legal requirements associated with these rights.

- Users may download and print one copy of any publication from the public portal for the purpose of private study or research.

- You may not further distribute the material or use it for any profit-making activity or commercial gain

- You may freely distribute the URL identifying the publication in the public portal 


\title{
Modelling the socio-economic impacts of modern bioenergy in rural communities in Ghana
}

\author{
Francis Kemausuor*, Simon Bolwig\# and Shelie Miller^^ \\ *Department of Agricultural Engineering, KNUST, Kumasi, Ghana \\ \#Technical University of Denmark, Frederiksborgvej 399, Building 110, 4000 Roskilde \\ ${ }^{\wedge}$ School of Natural Resources and Environment, University of Michigan, 440 Church St., Ann \\ Arbor, MI 48109-1041
}

\begin{abstract}
This study analyses ex-ante socio-economic impacts of biogas systems using a remote rural community in Ghana as a case study. An analysis was performed for a $300 \mathrm{~m}^{3}$ bio-digester that relies on crop residue and animal manure as feedstock to produce methane gas for cooking using selected bioenergy economic and social indicators. With a 10 percent discount rate, a 30 year bio-digester lifetime and methane tariff starting at US\$ $0.7 / \mathrm{m}^{3}$, the project will have a Net Present Value of approximately US\$22,000, 16 year payback and an Internal Rate of Return of $11 \%$. The project will create 4 full time unskilled labour positions during the investment year and 3 positions during operation years. Using methane from the bio-digester for cooking will displace approximately 170 tonnes of firewood per year and save the women in the community a total of 3,400 hours per year not fetching firewood. However, only $5 \%$ of households are willing to pay the base tariff of US $\$ 30 / \mathrm{m}^{3}$ with up to $60 \%$ willing to pay less than half the monthly tariff. To make tariffs affordable to rural households, there is the need for subsidy schemes from government or relevant agencies.
\end{abstract}

Keywords: Bioenergy; crop residues; socio-economic impacts; rural communities.

\section{Introduction}

Traditional biomass or woodfuel, in the form of firewood and charcoal, forms the greater part of cooking and heating fuel supply in low income countries (Coelho and Goldemberg, 2013). Even though Ghana is currently classified by the World Bank as a lower middle income country, its energy consumption pattern is no different from those of low income countries. Woodfuel remains the principal cooking and heating fuel in Ghana today. According to the 2010 housing and population census, more than $74 \%$ of Ghanaian households depend on woodfuel as their main source of cooking fuel (Ghana Statistical Services, 2012). The situation is worse in rural communities where $89 \%$ of households depend on woodfuel as main cooking and heating fuel source. Recent energy consumption data from the Ghana Energy Commission indicates that in the year 2012, woodfuel contributed $49.8 \%$ to the 268 PJ total energy consumed in Ghana (Energy Commission 2013a). In a business-as-usual scenario, the percentage share contribution of woodfuel to total energy supply could decrease but absolute consumption is expected to increase (Energy Commission 2013b). This has implications for forest degradation because over $90 \%$ of woodfuel consumed in Ghana is obtained directly from the natural forest (Arthur and Baidoo, 2011). The resulting net increase in forest degradation in Ghana averaged 115,000 ha/yr during the period 2000-2005 (FAO, 2010). Burning woodfuel in inefficient 
stoves also has health effects for households in poor rural communities. Data on health effects from indoor smoke in Ghana is not available but estimates from the World Health Organisation indicate that globally, over 1.6 million deaths a year are caused by exposure to solid fuel smoke resulting from the burning of traditional biomass (Perez-Padilla et al., 2010).

Efforts to curtail woodfuel consumption and fast-track the adoption of modern cooking fuels is a priority for most governments, led by the top echelons of global politics. The UN secretary general recently outlined a plan, called the 'Sustainable Energy for All' (SE4ALL) Initiative which seeks to 'catalyse major new investments to speed the transformation of the world's energy systems, pursue the elimination of energy poverty, and enhance prosperity' (United Nations, 2012). The SE4ALL initiative calls on all stakeholders to take concrete action towards three critical objectives to be achieved by 2030. The three objectives are (1) ensuring universal access to modern energy services; (2) doubling the global rate of improvement in energy efficiency; and (3) doubling the share of renewable energy in the global energy mix (United Nations, 2012). The initiative also seeks to assist low income countries with low access to modern energy to chart a path towards attaining an energy secured future by 2030, calling for decisive shift away from business-as-usual and increasing momentum for cleaner and more efficient energy solutions that can leapfrog existing systems.

In order to achieve the objectives of the SE4ALL initiative, several countries have also prepared or are in the process of preparing national action plans following the overall objectives of the UN Secretary General's SE4ALL plan. Ghana is the first country to have prepared a national SE4ALL country action plan (Mensah et al., 2014). The Ghana SE4ALL Country Action Plan concentrates initially on two main sources of clean modern energy - liquefied petroleum gas (LPG) and improved cookstoves - which are considered to have limited bottlenecks that can cost-effectively be removed through concerted action over the short to medium term (Government of Ghana, 2012). But even before the SE4ALL action plan, the Ministry of Energy in 2010 had also outlined an 'Energy Policy and Energy Sector Strategy' with a key policy objective to increase LPG access to households and public institutions from $9.5 \%$ in 2008 to at least $50 \%$ by 2015 . However, Mensah et al. (2014) argues that on a business-as-usual scenario, only $40 \%$ of households in Ghana could be using LPG as their main source of cooking fuel by 2020 with the $50 \%$ target being achieved closer to 2025 rather than the 2015 target set by the government.

Ghana's current LPG dissemination model requires that consumers own their bottles and commute to purchase LPG from retail filling-stations. However, LPG retail filling-stations are unevenly distributed across the nation and are only located in large urban areas, making it difficult for rural communities to access LPG (Kemausuor et al, 2012). Efforts to enable rural communities switch to modern fuels is one of the central themes of a recently approved Renewable Energy Act by the Parliament of the Republic of Ghana (Ministry of Energy, 2012) which aims to promote and support the increased use of improved biomass technologies through legislation, fiscal incentives and attractive packages. In the short to medium term, rural improved biomass technologies for cooking are expected to rely on bio-digesters producing methane gas. Traditionally, livestock manure, especially from cattle, is promoted as the feedstock of choice for rural bio-digesters in Ghana. But in most rural communities, cattle numbers are so few that they are hardly kept in housing structures (KITE, 2008). In Southern Ghana, manure may not be available in several rural communities due to the low level of livestock (KITE, 2008). It is therefore worth investigating to what extent bio-digesters can rely on other feedstock sources or a mix of livestock manure and other feedstock. 
Lately, researchers have been exploring the feasibility of using crop residues in bio-digesters in addition to manure, because of their abundance (Montoneri et al, 2009). Crop residues are obtained as a by-product of agricultural post-harvesting activities, usually from the processing of staple crops for domestic consumption and export (Perimenis et al., 2011; Mohammed et al., 2013). They include straw and husks of cereals such as rice, maize/corn, sorghum, and millet; peels and stalks of cassava and straw and pods from cowpea. The possibility to use crop residues as feedstock for bio-digesters will complement manure in communities where manure is not adequate for widespread dissemination of bio-digesters. However, using crop residues as feedstock for bio-digesters has challenges with respect to the yield of methane. Methane yield is affected by the composition and biodegradability of lignocelluose due to the recalcitrant nature of lignin (Frigon and Guiot, 2010; Chandra et al., 2012). These issues are the subject of ongoing technical research (Brown and Li, 2013; Chandra et al., 2012; Muhammad Nasir et al., 2012; Appels et al., 2011; Wu et al., 2010; Schievano et al., 2009; Xu and Li, 2012; Brown et al., 2012; Liew et al., 2012; Cui et al., 2011; Li et al., 2011).

In addition to the technical challenges, producing bioenergy from crop residues also present sustainability challenges. Issues regarding economic performance as well as environmental and social effects of using crop residues for bioenergy, especially in rural contexts, are not well established (Schwietzkeet al, 2008). Socio-economic impacts are diverse and will differ according to such factors as the nature of the technology, local economic structures, social profiles and production processes (Krajnc and Domac, 2007). Existing socio-economic studies have targeted purposefully cultivated energy crops or impacts at the wider national/regional level (Brose et al., 2010; Dam et al., 2009; Domac et al., 2004; Duer and Christensen, 2010; Lehtonen and Okkonen, 2013; Sathe and Bhosale, 2013; Silalertruksa et al., 2012; Stanojevic et al., 2006; Suthar, 2011; Dale et al., 2013a). Socio-economic impacts of modern bioenergy from crop residue and also at a rural community scale have not been the subject of much research. This study therefore aims to analyse the socio-economic impacts of rural community scale modern bioenergy production from a mix of crop residues and livestock manure using a rural community in Ghana as a case study. To achieve this, the specific objectives were to:

1. estimate recoverable crop residue and manure for bioenergy in the community;

2. develop a model for determining selected relevant socio-economic indicators of modern bioenergy, and to;

3. test the reliability of the model on a community case study.

To effectively assess the sustainability of bioenergy projects, many groups (for example the Roundtable of Sustainable Biofuels (2011), Global Bioenergy Partnership (2011), and Council on Sustainable Biomass Production (2011)) have established a set of indicators that can be used to quantify bioenergy sustainability. Indicators provide information about an energy system (Guy and Kibert, 1998) and show how well the system is working or help to determine what direction should be taken to address any issues with the system (Hiremath et al., 2013).

They can be appropriate tools for communicating and promoting dialogue related to sustainable development between stakeholders, policy makers and the public (Vera and Langlois, 2007) as well as enable decision makers to choose when, how, and where to deploy systems for sustainable development (Buchholz et al., 2007). Indicators of bioenergy sustainability can be applied conceptually to a region, but actual applications are context specific (Sovacool and Mukherjee, 2011). There are numerous indicators which often present a challenge to implementation (Dale et al., 2013b) and may lead to confusing rather than informing decision-makers (Junginger et al., 2011). Agreement on a few common measures of bioenergy system sustainability and selecting a small set of specific indicators requires 
compromise but is essential to develop bioenergy markets (Dale et al., 2013a; Dale et al., 2013b).

This study considered 16 bioenergy social and economic sustainability indicators developed by the Global Bioenergy Partnership (2011). These indicators include: allocation and tenure of land for new bioenergy production; price and supply of a national food basket; change in income; jobs in the bioenergy sector; change in unpaid time spent by women and children collecting biomass; bioenergy used to expand access to modern energy services; change in mortality and burden of disease attributable to indoor smoke; and incidence of occupational injury, illness and fatalities. The rest are: productivity; net energy balance; gross value added; change in consumption of fossil fuels and traditional use of biomass; training and requalification of the workforce; energy diversity; infrastructure and logistics for distribution of bioenergy; and capacity and flexibility of use of bioenergy. Some of the indicators are applicable at the national/regional level and are the subject of a different study by the authors. Others are also more applicable to first generation bioenergy that relies on agricultural lands. Again, some of the indicators mentioned above can only be assessed expost, using completed projects. This study therefore carefully considered all 16 indicators and selected 5 measurable indicators applicable to rural-scale crop residue and manure biodigester systems. The 5 indicators selected are: productivity (which include notable financial performance indicators such as Net Present Value, Internal Rate of Return and Payback); job creation; income effects; bioenergy to expand access to modern energy services; and change in unpaid time spent by women and children collecting biomass.

\section{Methodology}

\subsection{Model description}

A model was designed for bio-digester systems that rely on a combination of crop residue and livestock manure for the production of methane for cooking and heating within a rural community context. The model was designed to analyse the socio-economic impacts from the point of collecting crop residues and livestock manure to delivery of methane to a cooking area within the rural household. The stages considered in the model are shown in Figure 1.

General input variables into the model include amount of specific crops harvested in the community, number of cattle available within and outside the community, bio-digester component and accessories costs, biomass storage costs, land and labour costs, transport costs and methane sales. Key variables for digester inputs (crop residues, animal manure ${ }^{1}$ and water) include the cost of acquisition and transportation to the storage site or digester. The maximum size of the digester is estimated based on the annual supply of crop residues and livestock manure. Capital costs and maintenance costs are considered for a 30 year project implementation period. Revenues are analysed from the sales of methane to households/small businesses in the community. Net Present Value (NPV), Internal Rate of Return (IRR) and payback were used as economic performance indicators. Social indicators determined by the model are job creation, income effects, displacement of firewood from the use of methane and time saved by women and children collecting biomass in the community

\footnotetext{
${ }^{1}$ The combination of crop residue and animal manure are referred to as feedstock in this article
} 


\section{Figure 1}

\subsection{Base case scenario}

The base case is modelled ex-ante, on a potential $300 \mathrm{~m}^{3}$ bio-digester for Zambrama, a rural community in the Ashanti region of Ghana (Figure 2). The base case scenario uses data collected from Zambrama and other relevant sources and is assumed to be the most likely outcome, depending on the accuracy of the data collected. The Zambrama community lies in the transitional agro-ecological zone in Ghana and is accessible by feeder road. The digester design is based on the seasonal availability of corn stover from farmers in the community and the procurement of cattle manure from outside the community. Based on the experience of Ghanaian digester construction companies, it is assumed that the community will employ six fixed dome digesters, each of size $50 \mathrm{~m}^{3}$.The fixed dome plant (Figure 3) comprises a closed, dome-shaped digester with an immovable, rigid gasholder and a displacement pit, also named 'compensation tank' (Arthur et al., 2011). The gas is stored in the upper part of the digester, which replaces the need for a gas storage balloon. The slurry (or digestate) is displaced into the compensating tank when gas production starts.

\subsubsection{Input variables and data acquisition}

Table 1 lists selected input variables that were used for the base scenario. Data in Table 1 and other data for the base scenario were estimated using primary data from the following sources: (1) a questionnaire survey and focus-group discussion with farmers and household heads in the Zambrama community; (2) a questionnaire survey of cattle ranch owners in and around the Zambrama community; (3) field experiments conducted on farm plots and households in the Zambrama community; (4) personal interviews with two bio-digester construction companies in Ghana; and (5) personal interviews with managers of two biodigesters, an $8 \mathrm{~m}^{3}$ plant using human faecal waste as feedstock and an $800 \mathrm{~m}^{3}$ plant that is fed with different fruit wastes generated from fruit processing companies in Adeiso, a community in the Eastern Region of Ghana. The surveys and field experiments, details of which are presented next, were conducted between June and August 2013.

Table 1

\section{Farmer household and cattle ranch survey}

The survey conducted in Zambrama was done to obtain information on types of crops grown, size of farm plots, historical harvest patterns, existing uses of crop residue, distance of farm plots from community, labour availability and costs for harvesting and transporting various residue types, household fuel demand, perception and acceptability of methane as cooking fuel, willingness to pay for the methane and the use of digestate as organic fertilizer on farm plots. A total of 32 farmer households, with farm plots totalling approximately 200, acres were interviewed in the survey. Willingness-to-pay questions were deliberately targeted at heads of households and household members who were decision makers on fuel use and 
other household items. Twenty-one (21) respondents, representing 66\% of the total interviewed, were either heads of households or decision makers on fuel use. These respondents were asked how much they were willing to pay for methane on a monthly basis and their willingness to invest in gas stoves. Respondents who were not household heads and/or were not decision makers on household fuel use were exempted from answering willingness to pay questions. Because they did not have the decision making power, it was thought that their response will distort the survey.

Due to the absence of cattle ranches within the Zambrama community itself, a survey was conducted in surrounding communities to determine the availability of manure. The distance of the cattle ranches from the community ranged from $2 \mathrm{~km}$ to $20 \mathrm{~km}$. The majority of cattle ranches were located in Ejura, the district capital and about $20 \mathrm{~km}$ away from the Zambrama community. Ejura is one of the dominant cattle rearing communities in the country. The community is inhabited by migrants from the northern parts of the country who are more experienced with the raising of cattle than households in southern Ghana. The survey was structured to solicit information on cattle housing systems and existing uses of manure. The questions ranged from numbers of cattle raised, housing conditions, uses of manure and cost of manure in case the owners place any price value on it. In the base case scenario, it is assumed that crop residue and cattle dung comes at no cost, a direct result from the survey conducted in the community.

\section{Field/fuel use experiments}

Field/fuel use experiments were performed to determine parameters for specific activities relating to the consumption of fuel and operation of bio-digesters. The field experiments, described below, involved residue-to-product ratio determination of crops in the community, labour requirements for harvesting crop residues, labour requirements for fetching water from the community water source, and time taken for women to harvest firewood for household use. The household experiment was conducted to determine household fuel use in the community.

\section{Residue-to-product ratios}

To determine how much residue could be available from harvested crops, field experiments were performed in the harvest period to determine residue-to-product ratio (RPRs) of maize and cowpea. The community had a total of forty (40) households at the time of the survey, with farm plot sizes averaging 6.25 acres per household. With plot sizes averaging about 2 acres, there were approximately 120 farm plots in the community. Eight farm plots in total (four each for maize and cowpea) were randomly selected from different locations of the community, to roughly represent an east, west, north and south direction from the community. On each farm plot, the following procedure was used for the RPR measurements:

a) Four sub-plots each of size $20 \mathrm{~m}$ by $20 \mathrm{~m}$ square was obtained by random sampling and crops on those plots were harvested.

b) The residue to product ratio (RPR) of the various residues was determined using the harvested weight of the product and residues obtained from the plants.

c) An average RPR was determined for each farm plot and averaged for the community.

Field labour requirements 
To estimate labour requirements to harvest straw, four farmers in the community were hired to harvest straw and their work rate timed during the process. The farmers were asked to work at their usual pace in order to determine the optimum levels of straw harvest for analysis. The time elapsed and amount of straw harvested were recorded and averaged for all the participating farmers. The harvesting was done on 1st August 2013 when farmers were still harvesting maize and preparing the field for the second farming season in the year. Personal interviews were conducted among transport owners to sample views on the cost of conveying straw from the fields.

\section{Firewood harvest labour requirements}

Firewood harvesting in the community is often done by the women. Although women were asked during questionnaire survey how long it took to fetch firewood, field experiments were performed to ascertain these figures in a real life situation. Three women were hired and timed as they walked from their home to their usual firewood harvest sites. They were then made to harvest firewood and convey home. The time it took to perform the activity and travel as well as the amount of firewood conveyed home were recorded. Average figures were computed and used in the model.

\section{Woodfuel consumption estimation}

Amount of firewood displaced by biogas depends on household sizes, fuelwood characteristics, combination of fuels used and types of foods cooked (Chakrabarty et al., 2013). To establish fuel demand in the community, a Kitchen Performance Test (KPT) was conducted. KPT is a field test used to assess qualitative aspects of stove performance, compare the impact of different stoves or determine quantities of household fuel consumption in real-world settings (Harvey and Tomas, 2011). KPT can be simple or complex depending on the intended purpose and the size of the community. For detailed methodology, see Harvey and Tomas (2011). The KPT was performed between June 16 and 19, 2013, over three full days, requiring daily household visits for four days. Firewood and where applicable charcoal were weighed daily using Salter Brecknell Electro Samson digital hand-held scales ( $45 \mathrm{~kg}$ x $0.01 \mathrm{~kg}$ ). A KPT survey was also administered daily to record information on the number and type of meals prepared, and the number of people cooked for. Since the KPT required that the respondent must be present each day for fuel measurement and interview, ten households were selected based on consent and availability. Data was analysed using simple averages for the ten households over the three day period to determine average and per capita woodfuel consumption in the community.

\subsubsection{Financial evaluation metrics}

To determine the economic feasibility of the bio-digester, Net Present Value (NPV), Internal Rate of Return (IRR) and payback period were used. NPV is the sum of the present value of individual cash flows over the project lifetime. The IRR is the discount rate at which the incremental net benefit stream or incremental cash flow equal zero (Gittinger, 1982).

NPV is computed using Equation 1:

$N P V=\sum_{t=0}^{n} \frac{B_{t}-C_{t}}{(1+i)^{t}}$

IRR is computed using Equation 2 and is the discount rate ' $i$ ' such that: 
$0=\sum_{t=0}^{n} \frac{B_{t}-C_{t}}{(1+i)^{t}}$

where $B_{t}$ is the benefit in each year, $C_{t}$ are the costs in each year, $i$ is the interest (discount) rate, $t$ are numbers from $0,1,2,3, \ldots, n$ where $n$ is the number of years (life of biogas plant).

\section{Figure 2}

\section{Figure 3}

\section{Results and discussions}

This section presents the results of the analysis and the discussion. It begins with an analysis of the availability of biomass feedstock resources in the Zambrama community, followed an assessment of the social benefits of the project, i.e. job creation, income effects, replacement of firewood with methane gas and time saved by women harvesting firewood. Following the assessment of social benefits is a financial assessment that details the NPV, IRR, payback and other financial parameters of the base scenario, as well as a willingness to pay assessment. Sensitivity analyses, showing the effect of selected cost parameters, such as methane sales, government subsidy and effect of animal manure transport costs, on key financial indicators concludes this section.

\subsection{Resource availability}

Maize and cowpea are the most cultivated food crops in Zambrama. Figure 4 illustrates the quantity of maize and cowpea harvested in Zambrama over the 2011 and 2012 farming seasons. There are two farming seasons in each calendar year (shown as S1 and S2 in Figure 4). Season one begins in March/April - after a long dry spell that spans 3 to 4 months - and ends in August. Season two begins in August/September and crops are harvested between December and January. The estimation of crop residues in this study takes into account: a) annual grain (product) yields for different types of crops; b) crop residue-to-product ratios and c) residue removal rates; and d) competitive use of crop residues.

The farm plot survey established that farmers have no competing uses for maize residues. Maize residues are often burnt at the end of the farming season. Farmers opined that leaving maize straw on the field poses challenges when planting seeds for the following season, as residues impede the manual planting process, especially if tractor ploughing is not done well. For this reason, the majority of farmers in the community prefer to burn their maize fields before tractor ploughing. For cowpea however, farmers deliberately leave residues on the field (assuming they are not burnt by wild fires) to serve as soil nutrient when the field is ploughed. The period between the first and second season is short as harvesting of crops and planting for the next season is done almost simultaneously, often separated by days to a couple of weeks for field preparation, depending on weather patterns. For this period, farmers may choose to burn maize residues or leave them on the field before ploughing. The period between the second harvest of the year and the first harvest of the subsequent year is a three to four month dry spell (also known as 'harmattan' season) during which wild fires consume almost every residue left on farm plots.

The assessment of residues was therefore done for maize residues alone as it is not expected that cowpea residue will be available in abundant quantities for energy purposes. Using the last four seasons' average for maize harvested in the community, it is estimated that about 50 
tonnes of maize and 4 tonnes of cowpea are harvested each season by farmers surveyed in the community. Based on these figures, Table 2 shows an estimation of unused residue availability in the community. Even though maize residue is unused in the community, only a $30 \%$ recoverability is estimated for energy purposes to account for any environmental and economic uncertainties.

\section{Figure 4}

\section{Table 2}

With regards to manure, the survey covered 10 ranches that had a total cattle population of 360 or on the average 36 cattle per ranch. All the ranch managers interviewed indicated that they do not have any competing uses for manure. Manure is kept in the ranch and not discarded because it is expensive to do so (See Figure 5). In some of the ranches, cattle spend the night outside of the ranch during rainy season because of the depth of wet manure which makes sleeping uncomfortable. All the surveyed ranches were willing to give out manure at no cost.

For a $300 \mathrm{~m}^{3}$ digester, an estimated 160 tonnes of maize production per year (with $30 \%$ recoverable residue) and manure from 90 cattle is the approximate feedstock needed per year for operation. Daily manure production from cattle is estimated at about $20 \mathrm{~kg} / \mathrm{head}$ with a recoverability fraction of $60 \%$ (Junfeng et al., 2005). But cattle in the Ejura community spend half the day feeding outside the ranch and it has also been established that cattle breeds reared in Ghana and many other West African countries are small and undernourished, with less manure production as compared to better fed cattle breeds (KITE, 2008). For this reason, this study assumes just $6 \mathrm{~kg}$ of dung per day from each cattle and a moderate recoverability fraction of $20 \%$.

\section{Figure 5}

\subsection{Social benefits}

The important social benefits of a rural bioenergy programme are its ability to create employment and therefore provide income for rural households, displace the use of traditional fuels and reduce the time women spend harvesting firewood. The model assessed the employment possibilities for households in the Zambrama community, possible income for the community, firewood displaced per year from the use of modern bioenergy and time saved by women for not harvesting firewood as they switch to the use of methane gas for cooking.

\subsubsection{Job creation and income}


Table 3 provides details of direct jobs available in terms of man-hours per year. In the investment year, more skilled labour will be required for the construction of the bio-digester. The skilled labour category is made up of an excavator operator, supervisors and brick layers. It is expected that all unskilled labour will be sourced from the Zambrama community, to the extent that there is adequate human resource. The unskilled labour requirement in the investment year is equivalent to 4 people working full time for all business days in the year. In the operating years, the project would create 3 permanent full-time unskilled jobs and part time management position for regular monitoring of technical performance. Labour services in the operating years include those for loading of feedstock and monitoring of digester performance, harvesting of crop residues and the collection and bagging of manure for transport to the project site. The direct unskilled job creation is nearly one job per $100 \mathrm{~m}^{3}$ digester. This compares with the calculated direct employment of around one job for 11.7 family sized (ranging between 4 and $15 \mathrm{~m}^{3}$ ) digesters built (Buysman, 2009). Other indirect jobs include the regular transportation of feedstock to project site and the provision of water.

Income effects are directly related to the number of jobs created on the project. Using recent labour income trends in the country, unskilled labour man-hour rate is estimated at between US\$ 0.8 to US\$ 1 . This exceeds Ghana's minimum wage for the year 2013 which is GHC 5.24 or approximately US\$2.5 per day. The hourly wage is also higher than current labour rate in Zambrama which is approximately US\$ 0.5 per hour. In the investment year, nearly US\$ 8,000 will remain in the community from the use of unskilled labour for various activities relating to construction of the bio-digester and the biomass storage structure. In the first year of operation, regular unskilled labour will attract nearly US\$5,500 of income into the local economy, increasing at 5\% per year for the subsequent years. Other incomes will accrue from unskilled labour requirements for maintenance services and assistance with transportation of biomass to the project site.

\section{Table 3}

\subsubsection{Displacement of woodfuel and time savings}

All households in the Zambrama community use woodfuel for cooking and do not have access to any form of modern fuel. The closest LPG retail station to the community is more than 60 $\mathrm{km}$ away making it difficult for households to obtain and use LPG. Results from the kitchen performance test indicate that the average household in Zambrama consumes about $25 \mathrm{~kg}$ of woodfuel per day. The average household size for the surveyed households is 8 . This implies that the average person in Zambrama consumes approximately $3 \mathrm{~kg}$ of woodfuel per day. All the households rely on firewood with occasional additional charcoal use in a few households. All households in the community use the three-stone stove to burn firewood. The $300 \mathrm{~m}^{3}$ digester will produce on the average about $28,000 \mathrm{~m}^{3}$ of biogas per year for the community. Using biogas stoves with an assumed burning efficiency of 55\%, this amount of biogas will produce energy of over $92,000 \mathrm{kWh}$. The available energy will substitute about 170 tonnes of firewood per year, assuming a 12\% efficiency (Arthur and Baidoo, 2011) for the three-stone stove used in the Zambrama community. Displacing this amount of firewood has positive health implications for women who would hitherto cook in smoky kitchens.

The firewood collection field experiment conducted in Zambrama indicates that it takes approximately $30 \mathrm{mins}$ for women in the community to collect the average daily firewood 
requirement of $25 \mathrm{~kg}$ from fields around the community. The time taken to fetch firewood is relatively shorter compared to similar studies by Baniya (2007), World Bank (2006) and United Nations (1995) with estimates of between 1.2 to 2.5 hours. This may be explained by the remoteness of the Zambrama community, which means that wood is available within walking distance from the community and women do not have to travel far to fetch firewood. The average round-trip distance covered by women collecting daily firewood requirement in Zambrama is approximately $600 \mathrm{~m}$. The distance could be more than $600 \mathrm{~m}$ if women decided to collect firewood on their farm plots as part of routine farm visits. In the base scenario, using all the methane available will save time amounting to approximately 3,400 hours per year not collecting firewood. This is more than 9 hours saved per day by women in the community. Using the higher literature average of 2 hours per day collecting firewood, the time saved by women in the community could increase to 36 hours per day.

Besides woodfuel savings, households that switch to methane gas for cooking could also save cooking time. A study in Nepal shows that households with family sized biogas plants of approximately $2.4 \mathrm{~m}^{3}$ make savings of between $11-100 \mathrm{~kg}$ of woodfuel per month, 0-2.4 litres of kerosene per month and daily cooking time savings of between 1.5-5 hours (Chakrabarty et al., 2013). Another study found that family sized biogas plants in Cambodia displace between 1-2 kg per day per $\mathrm{m}^{3}$ of plant capacity and households saved around US $\$ 14.4 /$ month on energy with an extra incentive of US\$ 52 per year on chemical fertilizers (Buysman and Mol, 2013). Households using methane gas for cooking also saved on average around $1.5 \mathrm{~h}$ daily on fuel wood collection and cooking time. Another potential benefit, which is not the focus of this paper, is the use of the slurry on farm plots in the community which could serve as an income generating source for the project and displace the use of inorganic fertiliser.

\subsection{Financial analysis of base scenario}

The investment cost for the $300 \mathrm{~m}^{3}$ biogas digester, land and other accessories is approximately US $\$ 93,000$. Construction will take place in year 'zero' and then other indicators are modelled for a 30 year period, assumed to be the lifetime of the digester. Even though the digester is assumed to have a 30 year lifespan, other accessories such as storage structure and pre-treatment facilities are expected to be replaced every 5-10 years. The base scenario's NPV over the 30 year project lifetime of the project is US\$21,820 with an IRR of $11 \%$ as summarized in Table 4 . The payback is reached in the 15 year as illustrated by the cash flow analysis in Figure 6. As shown in Table 4, discontinuing the project after 10 years results in a negative NPV and IRR, rendering the project unprofitable for a commercial enterprise. Discontinuing after 20 years also results in an IRR that is less than the discount rate and an NPV that is still negative. Within the 30 year period of the project, the base scenario will deliver a total energy of about 5 million $\mathrm{kWh}$ at a total cost of US\$990,000, resulting in a levelised cost of approximately US\$ 0.20 per $\mathrm{kWh}$ of energy delivered to a household.

Over the lifetime of the project, transportation of feedstock and water constitute $55 \%$ or more than half of total project costs as summarised in Figure 7. Transport costs are high because in the base scenario, manure is transported to the project site through a $20 \mathrm{~km}$ distance. The base scenario also assumes that water will be transported by hired labour. These factors increase the cost of transportation considerably. Labour costs for feedstock collection and digester operation forms approximately $24 \%$ of total project costs. Digester establishment 
and maintenance costs play a less significant role accounting for less than $10 \%$ of expenses. In the base scenario, revenues are obtained exclusively from the sales of methane.

\section{Figure 6}

\section{Figure 7}

\section{Table 4}

\subsection{Willingness to pay}

In the Zambrama community, woodfuel is freely obtained from nearby trees at no monetary cost to households. Households also use three-stone stoves which come at no financial cost. The introduction of biomass digesters will necessitate the purchase of methane gas and gas stoves, using appropriate financial models or tariffs. One of the best tariff options for gas purchases is a monthly payment plan as the case is for electricity and water tariffs in Ghana. The financial indicators were modelled with an average methane tariff of US\$30 per household. The retail price of stoves were estimated using price quotations from the open market and ranged between US\$ 15 to US\$ 25 for 2 cooking space to 4 cooking spaces respectively. Of the respondents to whom willingness-to-pay questions were posed, all of them were able to state a price they were willing to pay per month for methane gas. As presented in Figure 8, only 5\% of respondents were willing to pay the highest price asked. Forty percent are able to pay up to half of the maximum amount. In effect, up to $60 \%$ of household decision makers are only willing to pay less than half of the maximum price stated. Willingness-to-pay for gas stoves were higher with close to $70 \%$ willing to pay the highest price of US\$25. Willingness-to-pay for stove may be higher because it occurs once every 3-5 years as opposed to monthly for methane gas. The results of this analysis raises subsidy issues which are important if rural community households would switch to modern fuels.

\section{Figure 8}

Because households in the community collect their own firewood and do not pay physical cash for it, methane may not be able to compete unless heavily subsidised, as also confirmed from the willingness to pay analysis. To make this attractive to rural communities, suitable financial schemes such as investment subsidy may be required. Subsidy schemes for biogas systems already exist in several developing countries which make it possible for rural households to switch to cleaner fuels. Household biogas systems in Ethiopia enjoy subsidies of between 34-36\% of the investment cost from the National Biogas Programme Ethiopia, depending on the size of the digester (Gwavuya et al., 2012). Prior to the year 2000, Chinese states subsidized biogas production through the provision of more land for farming, free technical and labour services, or supplied all the cement needed for construction which often accounted for $30 \%$ of the total cost (Ghimire, 2013). Since 2003, China has also provided direct funding for the construction of biogas plants of different scales in rural communities (Chen et al., 2010). In the height of India's biogas programmes in the early 90s, construction of biogas plants were supported with subsidies of between 32-40\% (Bhat et al., 2001). The aforementioned subsidy programmes have promoted biogas systems in developing countries 
and Ghana could adopt some best practices. Fortunately, subsidy schemes are not new in Ghana. As previously mentioned in preceding sections of this paper, other fuel types in Ghana, which are mainly used in urban communities, already attract subsidies from government and the subsidy net could be cast wider to support rural biogas programmes. Investment subsidies from government could come from the proposed renewable energy fund and other budgetary allocations for rural development. Government could also explore possibilities for carbon financing from appropriate carbon markets. The sensitivity analyses that follow explore the effect of government subsidy, as well as other key parameters on the profitability of the project.

\subsection{Sensitivity analysis}

\subsubsection{Effect of government subsidy with reduced methane tariff}

In most countries, the production of renewable fuels, including bioenergy attract incentives from governments in the form of subsidies and tax breaks (Bandyopadhyay et al., 2013; Devadoss and Bayham, 2010; Grafton et al., 2010; Josling, 2011; Kruse et al., 2007). As part of Ghana's Renewable Energy Act, a renewable energy fund (RE Fund) is proposed to be established. The objectives of the RE Fund is to provide financial resources for the promotion, development, sustainable management and utilization of renewable energy resources. Benefits from the fund include financial incentives to project developers, financing of feed-intariffs and equity based participation for almost all renewable energy forms. In the base scenario, there is no government subsidy to the project and the cost of methane is estimated to be equivalent to the retail cost of LPG in Ghana. The sensitivity analysis considers a government subsidy in the form of contribution to the capital cost of the digester and with a reduced methane tariff. The analysis considers a $20 \%$ reduction in the base methane tariff, making the cost equivalent to natural delivered to US residential consumers in August 2013 (US Energy Information Administration, 2013). The analysis considers subsidy contributions from government rising from $15 \%$ to $50 \%$ of the capital cost. Figure 9 shows the effect of changes in these two parameters on NPV and IRR. With the reduction in methane tariff, the NPV of the project remains negative until government subsidy reaches $50 \%$ of the biodigester capital cost. IRR also remains less than the discount rate until the $50 \%$ government subsidy is applied. Government subsidies of $15 \%$ and $30 \%$ will render the project unprofitable as the NPV is negative and the IRR falls below the discount rate.

Another form for government subsidy could be a direct subsidy to the price of methane purchased by households. For example, government could pay $50 \%$ of the methane tariff and credit it to appropriate funding budgets, which could be the RE Fund, an environmental fund or some form of carbon financing source. Direct government subsidy is already applied on LPG and electricity as well as transportation fuels in Ghana (Mensah et al., 2014; BroniBediako and Dankwa, 2013; Arze del Granado and Coady, 2012). Of critical importance is the appropriate targeting of the subsidy scheme, ensuring that it ends up at intended destinations.

\section{Figure 9}

\subsubsection{Effect of government subsidy with reduced methane tariff and 'zero' manure transport cost}


In most bioenergy projects, feedstock costs form the major cost component (Miao et al., 2012). In the base scenario, it is assumed that feedstocks are obtained at no cost, making transportation the major cost component. Transportation of feedstock and water constitute more than $57 \%$ of the total project cost over the 30 year period. Manure transport alone constitute a third of transportation costs. The high cost of manure transport is explained by the fact that in the base scenario, manure is sourced from outside the community from about $20 \mathrm{~km}$ away. It is therefore important to establish the impact of manure transport cost on project financial indicators in order to determine the profitability of this project in communities that have adequate manure. This section of the sensitivity analysis considers subsidy requirement from government to ensure project profitability, still with the same reduction in methane tariff as before, but this time also with no transport cost for manure. Figure 10 illustrates the effect of changes in these parameters on the NPV and IRR. Project becomes profitable from $10 \%$ government subsidy or higher. At $20 \%$ tariff reduction and $30 \%$ government subsidy, NPV is just slightly higher than the base scenario NPV (at US\$ 23,700 compared to US $\$ 21,820$ in the base scenario) with an IRR of $12 \%$, compared to $11 \%$ in the base scenario.

\section{Figure 10}

\section{Conclusions}

For a lower middle income country, up to a third of households in Ghana use woodfuel as their main source of cooking fuel. The situation is worse in rural communities where abundant crop residues could be used to generate energy and transition rural households to modern fuels. This study examined the socio-economic impacts of introducing crop residue bio-digesters in Ghanaian rural communities. A model was developed and used as a case study for Zambrama, a remote rural community in the Ashanti Region of Ghana. The study found that maize residues in the community have no competing uses and would be available for energy purposes.

Using a discount rate of $10 \%$ for a 30 year project lifetime, the NPV and IRR of the base scenario were US\$22,000 and $11 \%$ respectively for a $300 \mathrm{~m}^{3}$ bio-digester. The project will create 4 full time unskilled labour positions for community residents in the investment year and 3 full time positions for the subsequent 30 years of the project lifetime. The energy available can substitute up to 170 tonnes of firewood and save the women 3,400 hours per year not collecting firewood. However, households in the community are not willing to pay the tariff for methane gas which calls for some government subsidy in the form of capital cost contribution to the project and/or subsidy towards tariff. Sensitivity analysis shows with a $20 \%$ decrease in methane tariff, project only becomes profitable when a $50 \%$ government subsidy is applied. If manure transport costs were ignored, a 10\% government subsidy is just enough to make NPV positive, with an IRR higher than the discount rate.

The development of bio-digesters to provide modern cooking fuels in rural communities has been a success in Asia with notable success stories in China, India and Nepal. These success stories were supported by government legislation and were aimed at reducing forest degradation and introducing environmentally friendly fuel to an ever growing rural population. Fortunately, recent legislation in Ghana is supportive of such schemes. The Renewable Energy Act encourages the use of biomass to generate energy, especially for rural 
applications. A Draft Bioenergy Policy Document which is being finalised for cabinet approval has also reiterated that an effective strategy to address the energy needs of majority of the rural population is to promote the climbing of the energy ladder. The policy document place important emphasis on the need to move rural households from traditional biomass fuels to more convenient, efficient forms of energy - liquid or gaseous fuels for cooking and heating and electricity for lighting. To move from the present to the stage envisaged will require substantial funding and it is hoped that government will establish the necessary funding scheme to make this a reality. Going forward, government must speed-up the establishment of the RE Fund and pilot some of these rural energy intervention projects in order to examine their feasibility for widespread dissemination in rural communities. This will ensure that rural communities that do not have access to LPG for cooking can have access to biogas plants.

\section{Acknowledgement}

This work was supported with a grant from Danida Fellowship Centre (DFC) of the Danish Ministry of Foreign Affairs, as a part of the project "Biofuel production from lignocellulosic materials - 2GBIONRG", DFC journal no. 10-018RISØ. For additional information, see http://2gbionrg.dk.

Model preparation and drafting of manuscript was carried out during a research stay at the University of Michigan as part of the University of Michigan African Presidential Scholars (UMAPS) Program.

\section{References}

Appels, L., Lauwers, J., Degreve, J., Helsen, L., Lievens, B., Willems, K., et al., 2011. Anaerobic digestion in global bio-energy production: Potential and research challenges. Renewable \& Sustainable Energy Reviews, 15, 4295-4301.

Arthur, R., Baidoo, M.F., 2011. Harnessing methane generated from livestock manure in Ghana, Nigeria, Mali and Burkina Faso. Biomass and Bioenergy, 35, 4648-4656.

Arthur, R., Baidoo, M.F., Antwi, E., 2011. Biogas as a potential renewable energy source: A Ghanaian case study. Renewable Energy, 36, 1510-1516.

Arze del Granado, F.J., Coady, D., 2012. The unequal benefits of fuel subsidies. World Development, 40, 2234-2248.

Bandyopadhyay, S., Bhaumik, S., Wall, H.J., 2013. Biofuel Subsidies and International Trade. Economics \& Politics, 25, 181-199.

Baniya, A., 2007. Household characteristics and perception of users towards the environmental changes within community forests in the Dhaulagiri hills of Nepal. Banko Janakari, 16, 35-40.

Bhat, P.R., Chanakya, H.N., Ravindranath, N.H., 2001. Biogas plant dissemination: success story of Sirsi, India. Energy for Sustainable Development, 5, 39-46. 
Broni-Bediako, E., Dankwa, O.K., 2013. Assessment Of Liquefied Petroleum Gas (LPG) Utilisation In Ghana - A Study at Tarkwa. International Journal of Scientific \& Technology Research, 2, 2277-2286.

Brose, I., Stappen, F.V., Castiaux, A., 2010. Articulation of environmental and socio-economic externalities from bioenergy. Management of Environmental Quality, 21, 812-829.

Brown, D., Li, Y., 2013. Solid state anaerobic co-digestion of yard waste and food waste for biogas production. Bioresource technology, 127, 275-280.

Brown, D., Shi, J., Li, Y., 2012. Comparison of solid-state to liquid anaerobic digestion of lignocellulosic feedstocks for biogas production. Bioresource technology, 124, 379-386.

Buchholz, T.S., Volk, T.A., Luzadis, V.A., 2007. A participatory systems approach to modeling social, economic, and ecological components of bioenergy. Energy Policy, 35, 6084-6094.

Buysman, E., 2009. Anaerobic digestion for developing countries with cold climates. Wageningen University, Wageningen

Buysman, E., Mol, A.P.J., 2013. Market-based biogas sector development in least developed countries - The case of Cambodia. Energy Policy, 63, 44.

Chakrabarty, S., Boksh, F.I.M.M., Chakraborty, A., 2013. Economic viability of biogas and green self-employment opportunities. Renewable and Sustainable Energy Reviews, 28, 757-766.

Chandra, R., Takeuchi, H., Hasegawa, T., 2012. Methane production from lignocellulosic agricultural crop wastes: A review in context to second generation of biofuel production. Renewable and Sustainable Energy Reviews, 16, 1462-1476.

Chen, Y., Yang, G., Sweeney, S., Feng, Y., 2010. Household biogas use in rural China: A study of opportunities and constraints. Renewable and Sustainable Energy Reviews, 14, 545-549.

Coelho, S.T., Goldemberg, J., 2013. Energy Access: Lessons Learned in Brazil and Perspectives for Replication in Other Developing Countries. Energy Policy, 61, 1088-1096.

Council on Sustainable Biomass Production, 2010. Draft Provisional Standard for Sustainable Production of Agricultural Biomass, Council on Sustainable Biomass Production. Accessed 21 December 2013 from http://www.fao.org/bioenergy/281850c80b63a4db091a00b2e1cb187f714e73.pdf

Cui, Z., Shi, J., Li, Y., 2011. Solid-state anaerobic digestion of spent wheat straw from horse stall. Bioresource technology, 102, 9432-9437.

Dale, V.H., Efroymson, R.A., Kline, K.L., Langholtz, M.H., Leiby, P.N., Oladosu, G.A., et al., 2013b. Indicators for assessing socioeconomic sustainability of bioenergy systems: A short list of practical measures. Ecological Indicators, 26, 87-102.

Dale, V.H., Langholtz, M.H., Wesh, B.M., Eaton, L.M., 2013a. Environmental and Socioeconomic Indicators for Bioenergy Sustainability as Applied to Eucalyptus. International Journal of Forestry Research, 2013, 1-10. 
Dam, J.M.C.v., Hilbert, J., Turkenburg, W.C., Petruzzi, H., Faaij, A.P.C., 2009. Large-scale bioenergy production from soybeans and switchgrass in Argentina : Part B, Environmental and socio-economic impacts on a regional level. Renewable and Sustainable Energy Reviews, $13,1679-1709$.

Devadoss, S., Bayham, J., 2010. Contributions of US crop subsidies to biofuel and related markets. Journal of agricultural and applied economics, 42, 743-756.

Domac, J., Krajnc, N., Risovic, S., Myles, H., Segon, V., 2004. Modelling socio-economic impacts of biomass energy utilization. Socijalna Ekologija, 13, 365.

Duer, H., Christensen, P.O., 2010. Socio-economic aspects of different biofuel development pathways. Biomass and Bioenergy, 34, 237-243.

Energy Commission, 2013a. National Energy Statistics 2000-2012. The Energy Commission. Accessed 15 September, 2013 from http://www.energycom.gov.gh/files/Ghana Energy Statistics 2012 AUG.pdf

Energy Commission, 2013b. 2013 energy supply and demand outlook for Ghana. Accessed 20 September from http://www.energycom.gov.gh/files/Energy\%20Commission\%20\%202013\%20Energy\%200utlook\%20for\%20Ghana.pdf.

FAO, 2010. Global forest resources assessment. Food and Agriculture Organisation of the United Nations. FAO Forestry Paper 163.

Frigon, J., Guiot, S.R., 2010. Biomethane production from starch and lignocellulosic crops: A comparative review. Biofuels, Bioproducts and Biorefining, 4, 447-458.

Ghana Statistical Services, 2012. 2010 Population and Housing Census: Summary of Final Results. Accessed 23 December 2013 from http://www.statsghana.gov.gh/docfiles/2010phc/Census2010_Summary_report_of_final_res ults.pdf

Ghimire, P.C., 2013. SNV supported domestic biogas programmes in Asia and Africa. Renewable Energy, 49, 90-94.

Gittinger, J.P., 1982. Economic Analysis of Agricultural Projects, second edition, John Hopkins University Press, Baltimore.

Global Bioenergy Partnership, 2011. The Global Bioenergy Partnership sustainability indicators for bioenergy, First Edition. GBEP Secretariat, FAO, Environment, Climate Change and Bioenergy Division, Rome, Italy. Accessed 21 December from http://www.globalbioenergy.org/fileadmin/user upload/gbep/docs/Indicators/The GBEP S ustainability Indicators for Bioenergy FINAL.pdf

Government of Ghana, 2012. Ghana sustainable energy for all action plan. Accessed 17 September from energycom.gov.gh/files/SE4ALL-GHANA\%20ACTION\%20PLAN.pdf 
Grafton, R.Q., Kompas, T., Long, N.V., 2010. Do Biofuel Subsidies Reduce Greenhouse Gas Emissions? International and Development Economics, International and Development Economics Working Papers, 2010, 38 pp, 1-38.

Guy, G. B., Kibert, C.J., 1998. Developing indicators of sustainability: US experience. Building Research \& Information, 26, 39-45.

Gwavuya, S.G., Abele, S., Barfuss, I., Zeller, M., Müller, J., 2012. Household energy economics in rural Ethiopia: A cost-benefit analysis of biogas energy. Renewable Energy, 48, 202-209.

Harvey, A., Tomas, A., 2011. Guidelines for field performance tests of energy saving devices and kitchen performance tests. ClimateCare Oxford, UK

Hiremath, R.B., Balachandra, P., Kumar, B., Bansode, S.S., Murali, J., 2013. Indicator-based urban sustainability-A review. Energy for Sustainable Development, 17, 555-563.

Josling, T., 2011. The future of biofuel subsidies. Biofuels, 2, 243-245.

Junfeng, L., Runqing, H., Yanqin, S., Jingli, S., Bhattacharya, S.C., Abdul Salam, P., 2005. Assessment of sustainable energy potential of non-plantation biomass resources in China. Biomass and Bioenergy, 29, 167-177.

Junginger, M., van Dam, J., Zarrilli, S., Ali Mohamed, F., Marchal, D., Faaij, A., 2011. Opportunities and barriers for international bioenergy trade. Energy Policy, 39, 2028-2042.

Kemausuor, F., Brew-Hammond, A., Obeng, G.Y., Duker, A., Annor, F.O., Boamah, F., et al., 2012. GIS-based support for implementing policies and plans to increase access to energy services in Ghana. Report to the European Union Energy Initiative Partnership Dialogue Facility (EUEIPDF), Contract no.: 81121090: Kumasi.

KITE, 2008. Feasibility study report on domestic biogas in Ghana - Report Submitted by Kumasi Institute of Technology, Energy and Environment (KITE) to the Shell Foundation.

Krajnc, N., Domac, J., 2007. How to model different socio-economic and environmental aspects of biomass utilisation: Case study in selected regions in Slovenia and Croatia. Energy Policy, 35, 6010-6020.

Kruse, J., Westhoff, P., Meyer, S., Thompson, W., 2007. Economic Impacts of Not Extending Biofuel Subsidies. AgBioForum, 10, 94-103.

Lehtonen, O., Okkonen, L., 2013. Regional socio-economic impacts of decentralised bioeconomy: a case of Suutela wooden village, Finland. Environment, Development and Sustainability, 15, 245-256.

Li, Y., Yan, X., Fan, J., Zhu, J., Zhou, W., 2011. Feasibility of biogas production from anaerobic co-digestion of herbal-extraction residues with swine manure. Bioresource technology, 102, 6458-6463.

Liew, L.N., Shi, J., Li, Y., 2012. Methane production from solid-state anaerobic digestion of lignocellulosic biomass. Biomass and Bioenergy, 46, 125-132. 
Mensah, G. S., Kemausuor, F., Brew-Hammond, A., 2014. Energy access indicators and trends in Ghana. Renewable and Sustainable Energy Reviews, 30, 317-323.

Miao, Z., Shastri, Y., Grift, T.E., Hansen, A.C., Ting, K.C., 2012. Lignocellulosic biomass feedstock transportation alternatives, logistics, equipment configurations, and modeling. Biofuels, Bioproducts and Biorefining, 6, 351-362.

Ministry of Energy, 2012. Renewable energy policy and regulatory framework and renewable energy law for Ghana - electricity generation. Volume 1, Ministry of Energy, Accra, Ghana.

Mohammed, Y.S., Mokhtar, A.S., Bashir, N., Saidur, R., 2013. An overview of agricultural biomass for decentralized rural energy in Ghana. Renewable and Sustainable Energy Reviews, $20,15-22$.

Montoneri E., Savarino P., Bottigliengo S., Boffa V., Prevot A.B., Fabbri D. et al., 2010. Biomass wastes as renewable source of energy and chemicals for the industry with friendly environmental impact. Fresenius Environ Bull, 18 (2), 219-223

Muhammad Nasir, I., Mohd Ghazi, T.I., Omar, R., 2012. Production of biogas from solid organic wastes through anaerobic digestion: a review. Applied Microbiology and Biotechnology, 95, 321-329.

Perez-Padilla, R., Schilmann, A., Riojas-Rodriguez, H., 2010. Respiratory health effects of indoor air pollution. The international journal of tuberculosis and lung disease : the official journal of the International Union against Tuberculosis and Lung Disease, 14, 1079-1086.

Perimenis, A., Walimwipi, H., Zinoviev, S., Müller-Langer, F., Miertus, S., 2011. Development of a decision support tool for the assessment of biofuels. Energy Policy, 39, 1782-1793.

Roundtable of Sustainable Biofuels, 2011. Indicators of compliance for the RSB EU RED principles and criteria (Version 2). Accessed 20 December 2013 from http://rsb.org/pdfs/standards/RSB-EU-RED-Standards/10-12-13-RSB-IND-11-001-20-001RSB-EU-RED-Indicators-vers-2-0.pdf

Sathe, S.S., Bhosale, L.J., 2013. Socio-Economic Aspects of Mangroves: Potential of Biogas Production. Nature, Environment and Pollution Technology, 12, 147-149.

Schievano, A., D'Imporzano, G., Adani, F., 2009. Substituting energy crops with organic wastes and agro-industrial residues for biogas production. Journal of environmental management, 90, 2537-2541.

Schwietzke, S., Ladisch, M., Russo, L., Kwant, K., Mäkinen, T., Kavalov, B., Maniatis, K., Zwart, R, Shahanan, G., Sipila, K., Grabowski, P., Telenius, B., White, M. and Brown, A., 2008. Analysis and identification of gaps in research for the production of second-generation liquid transportation biofuels, IEA Bioenergy Task 41.

Silalertruksa, T., Gheewala, S.H., Huenecke, K., Fritsche, U.R., 2012. Biofuels and employment effects: Implications for socio-economic development in Thailand. Biomass and Bioenergy, 46, 409-418. 
Sovacool, B.K., Mukherjee, I., 2011. Conceptualizing and measuring energy security: A synthesized approach. Energy, 36, 5343-5355.

Stanojevic, M., Vranes, S., Gokalp, I., 2006. Initial results of socio-economic analysis for biofuelproduction in Europe. WSEAS Transactions on Environment and Development, 2, 3846.

Suthar, S., 2011. Utilizing livestock waste solids as bioresource for socio-economic sustainability: a report from rural India. Reviews in Environmental Science and Bio/Technology, 10, 193-197.

United Nations, 1995. The World's Women: Trends and Statistics. New York: United Nations.

United Nations, 2012. Sustainable Energy for all: A global action agenda - pathways for concerted action toward sustainable energy for all. Accessed 12 October 2013 from http://www.se4all.org/wp-content/uploads/2014/01/SEFA-Action-Agenda-Final.pdf

US Energy Information Administration, 2013. United States price of natural gas delivered to residential consumers. Available from http://www.eia.gov/dnav/ng/hist/n3010us3m.htm

Vera, I., Langlois, L., 2007. Energy indicators for sustainable development. Energy, 32, 875882.

World Bank, 2006. Gender, Time Use, and Poverty in Sub-Saharan Africa. World Bank Working Paper No. 73. Available from http://siteresources.worldbank.org/INTAFRREGTOPGENDER/Resources/gender_time_use_p ov.pdf

Wu, X., Yao, W., Zhu, J., Miller, C., 2010. Biogas and CH4 productivity by co-digesting swine manure with three crop residues as an external carbon source. Bioresource technology, 101, 4042-4047.

Xu, F., Li, Y., 2012. Solid-state co-digestion of expired dog food and corn stover for methane production. Bioresource technology, 118, 219-226. 
FIGURES

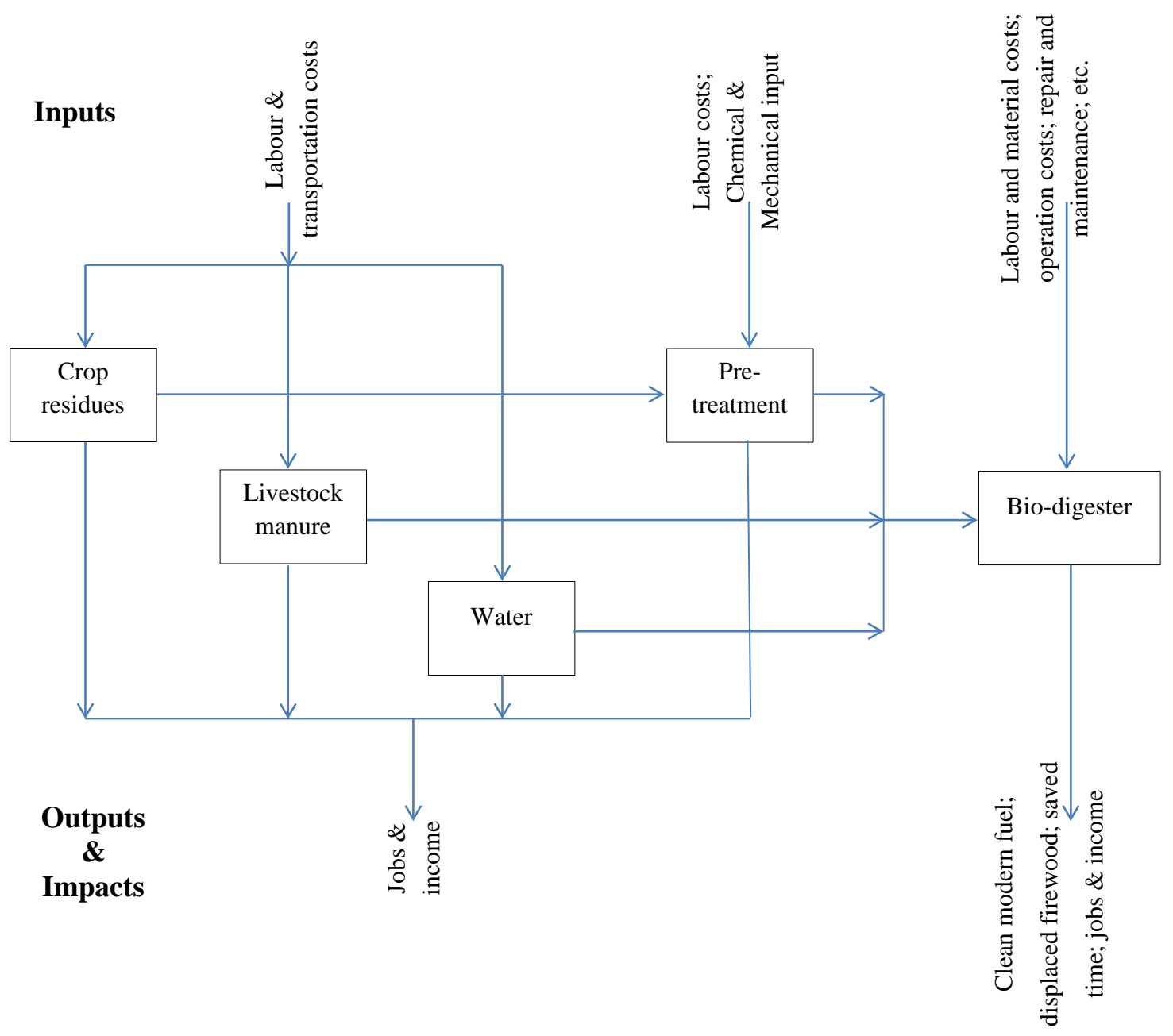

Figure 1: Flow diagram of residue biogas system 


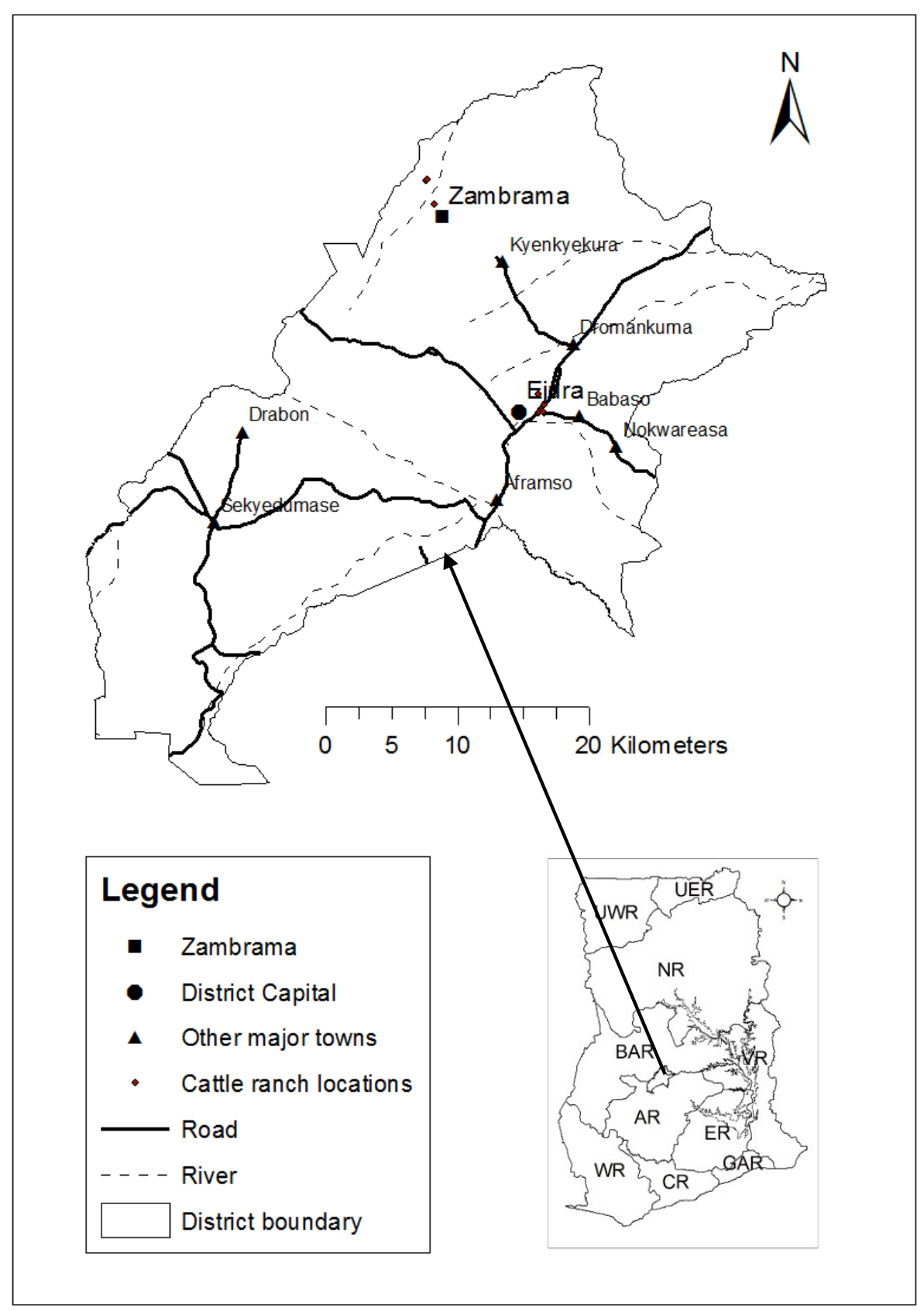

Figure 2: A map of Ghana showing location of Zambrama 


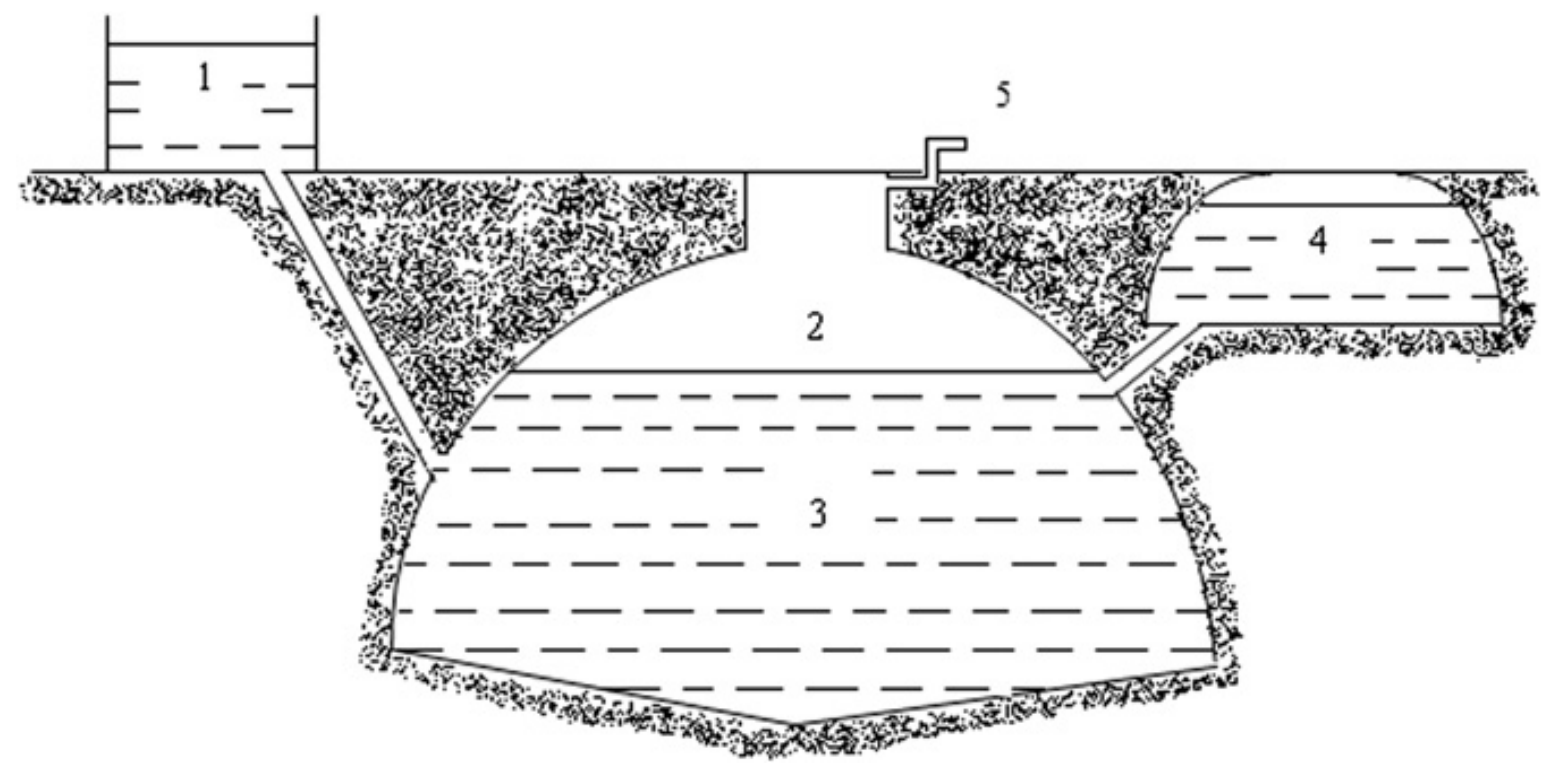

Fig. 3. Fixed dome digester

1. Mixing tank with inlet pipe. 2. Gasholder. 3. Digester. 4. Compensation tank. 5. Gas pipe. Source: (Arthur et al., 2011)

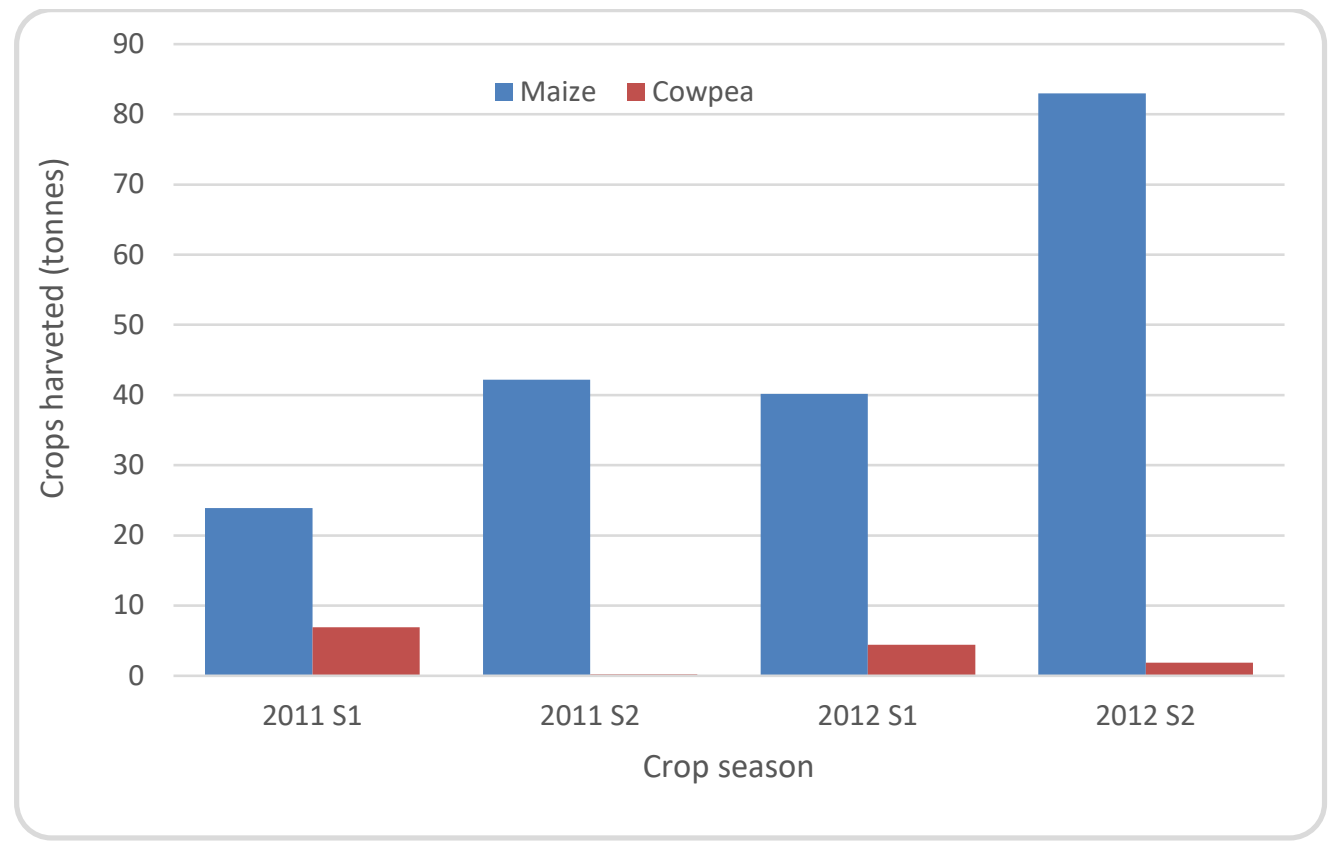

Figure 4: Crop harvest pattern in Zambrama. S1 - Season 1; S2 - Season 2 


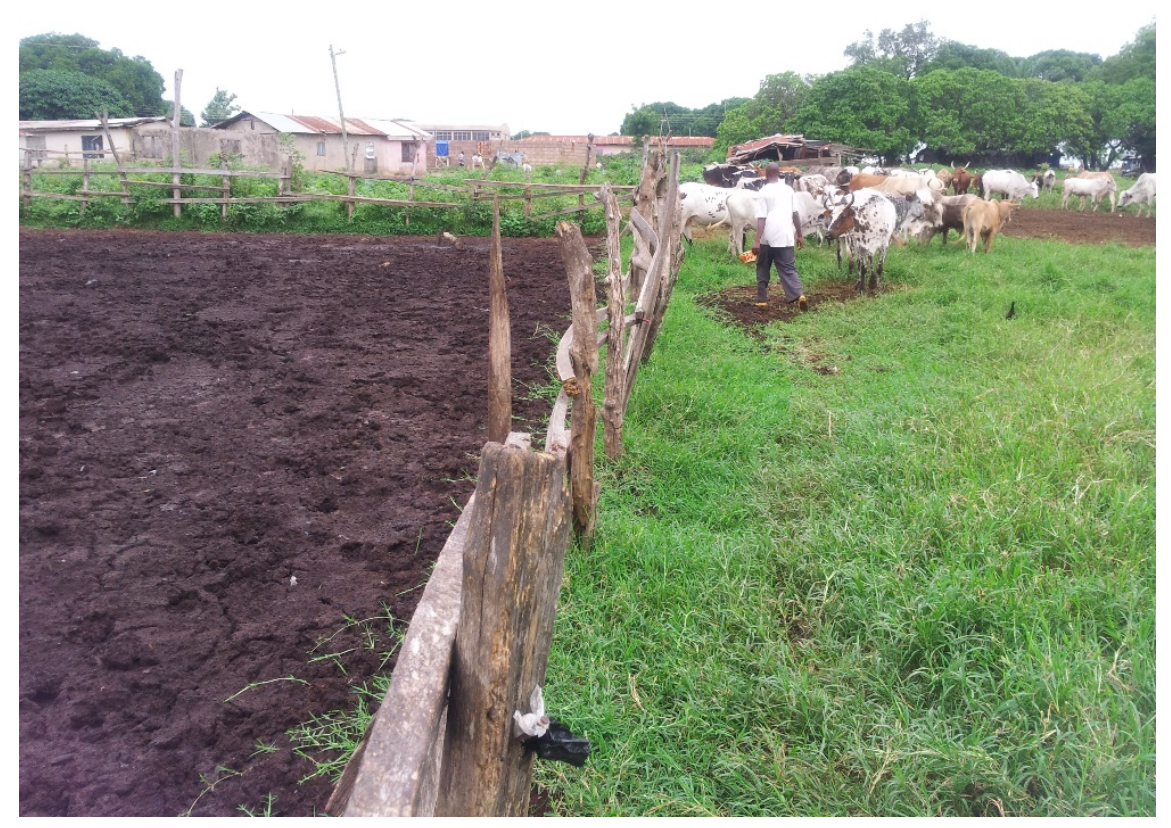

Figure 5: Cattle manure in a ranch in Ejura

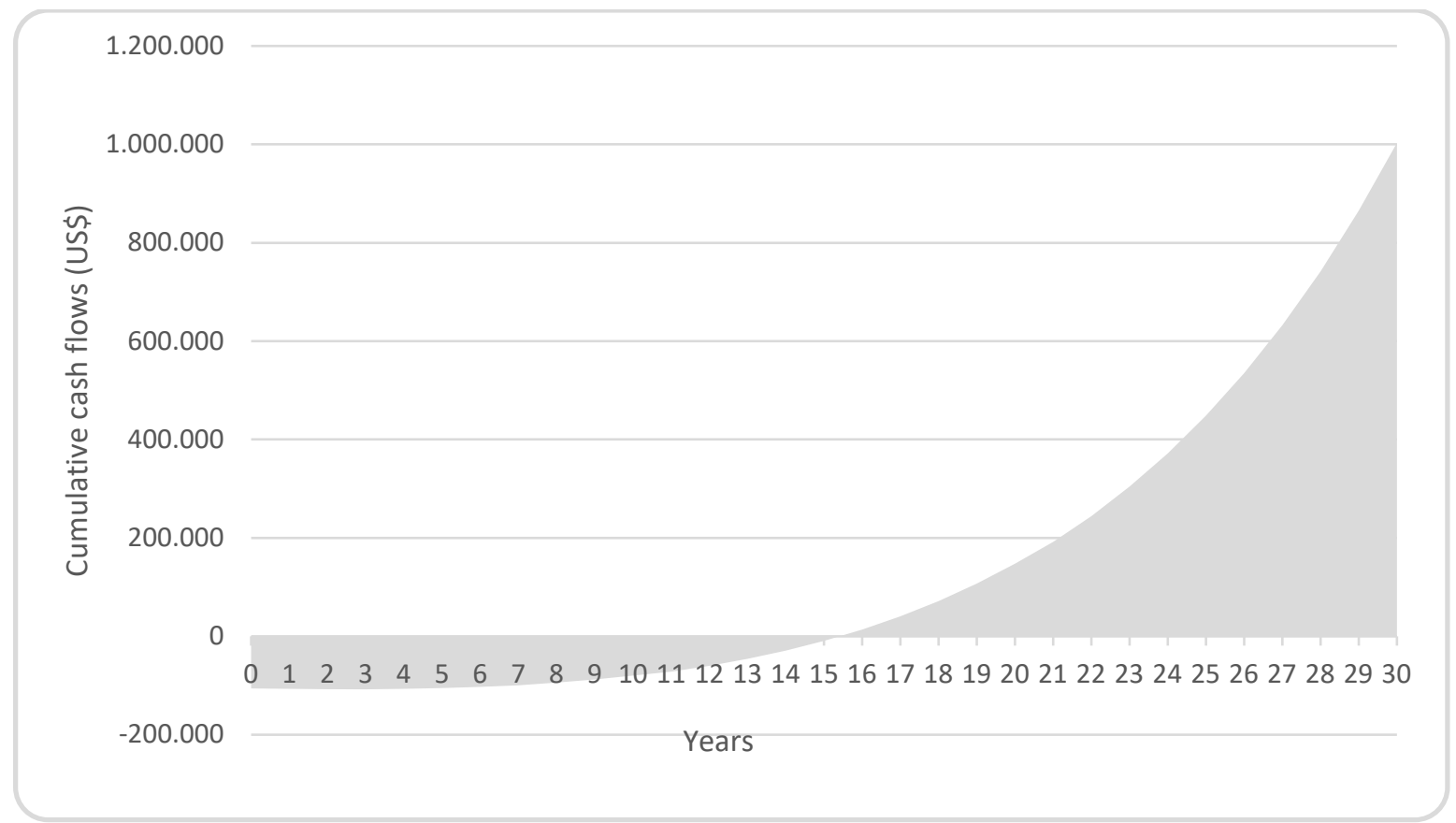

Figure 6: Cumulative cash flow of base scenario 


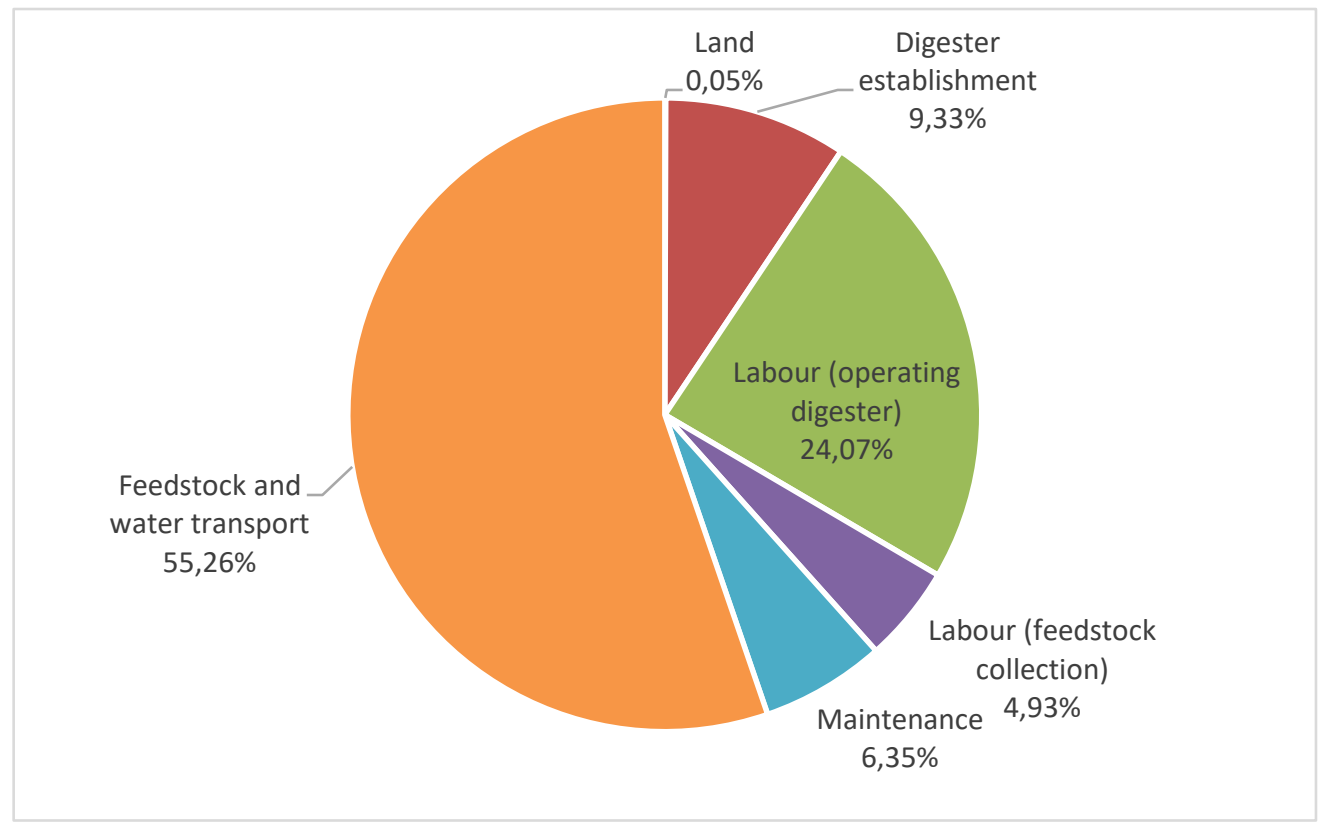

Figure 7: Distribution of total production costs over project lifetime

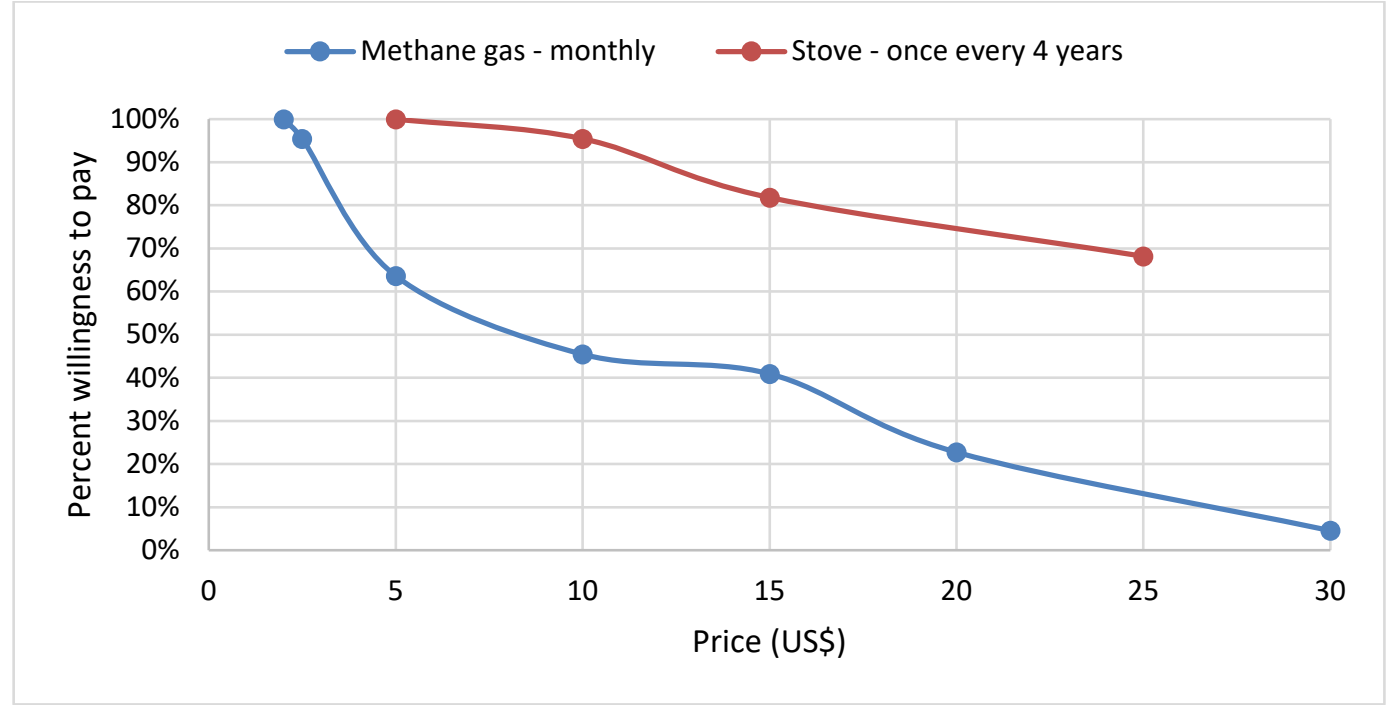

Figure 8: Willingness-to-pay for methane gas and stove 


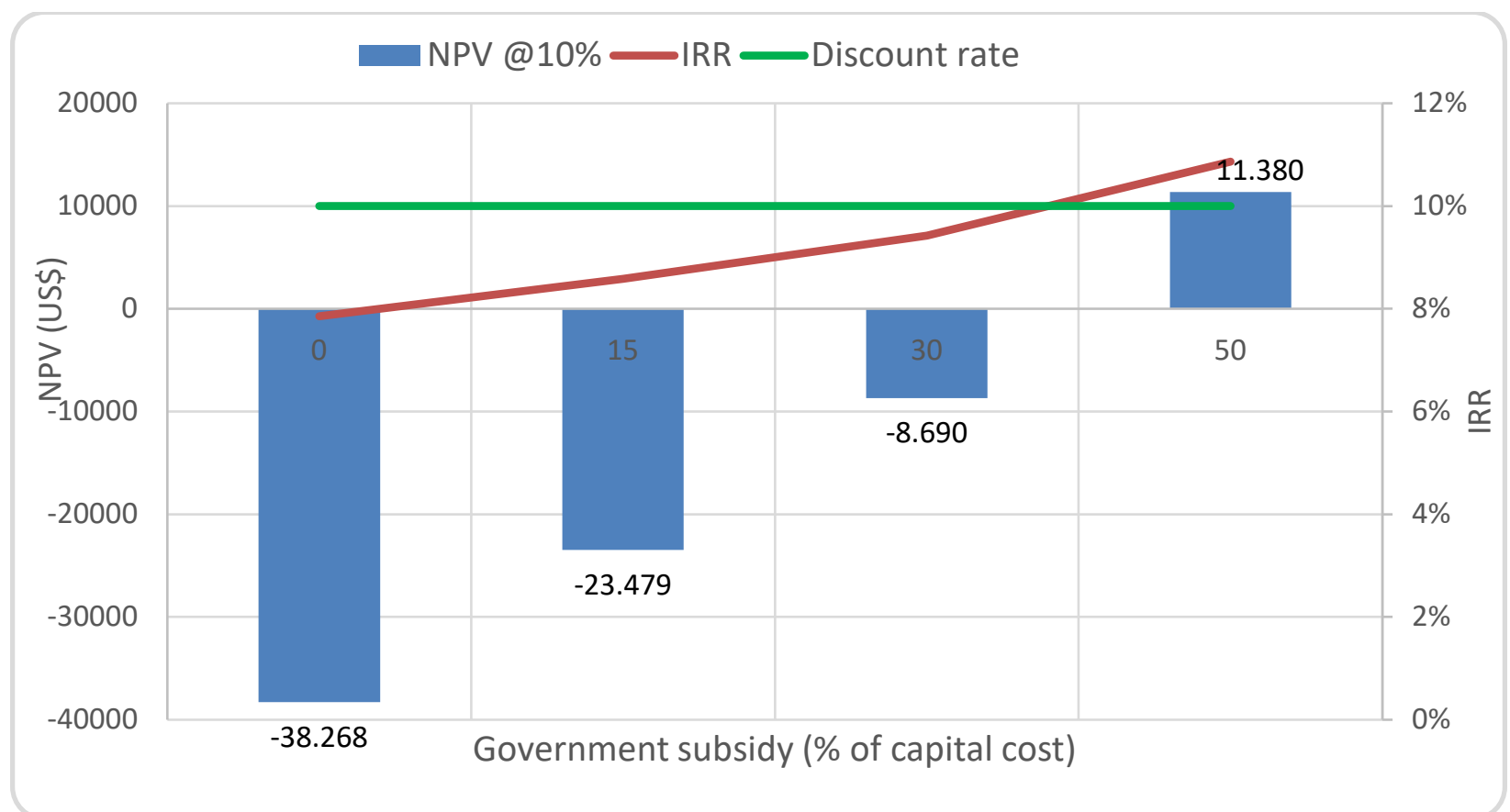

Figure 9: Effect of government subsidy with reduced tariff 


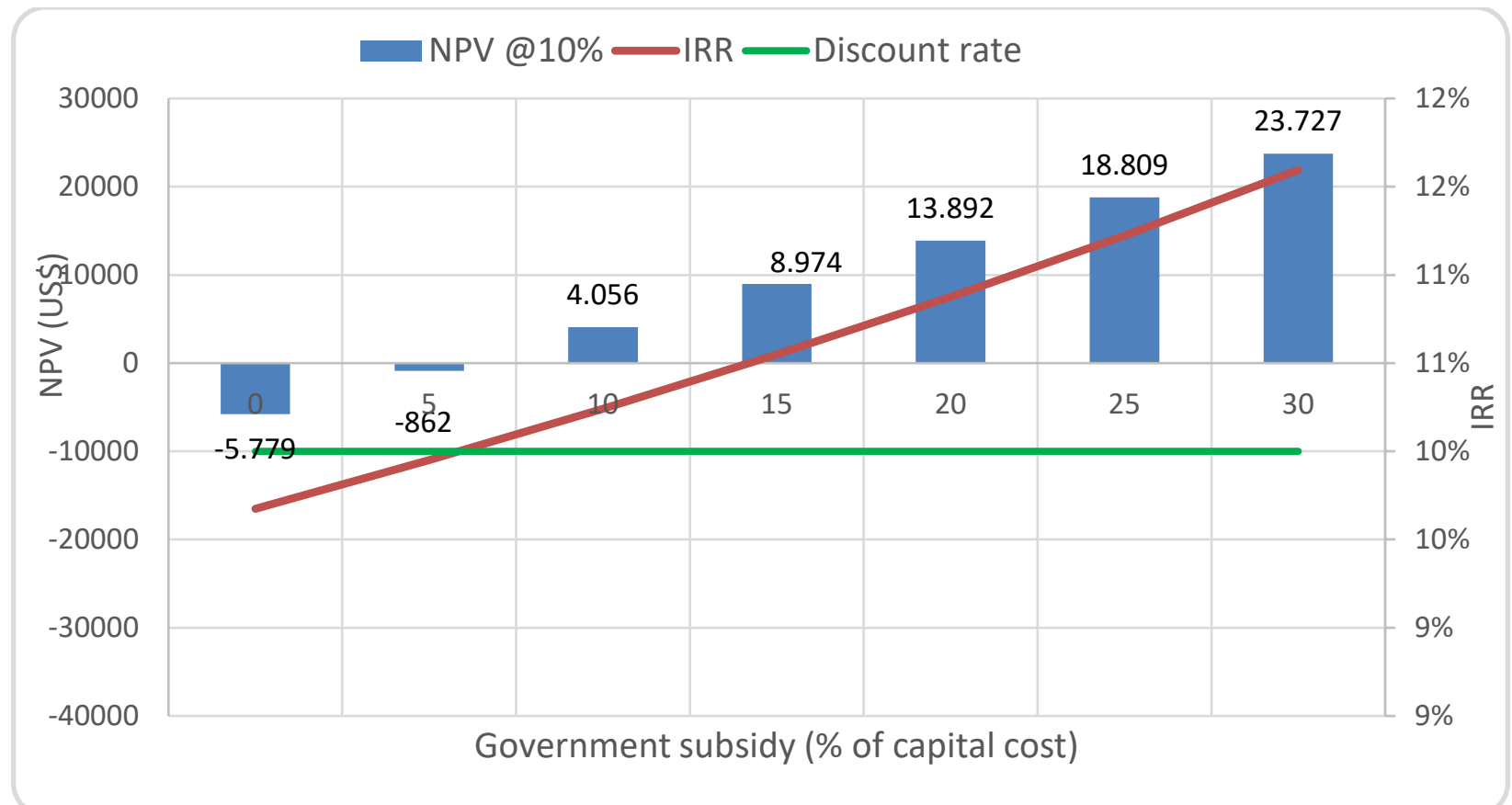

Figure 10: Effect of government subsidy with reduced tariff and manure transport cost 
Table 1: Selected input variables for base scenario

\begin{tabular}{|c|c|c|c|}
\hline Variable type & Variable description & Values & Unit \\
\hline \multirow[t]{5}{*}{ General } & Engineer & 10 & US\$ /man-hour \\
\hline & Supervisor & 4 & US\$ /man-hour \\
\hline & Other Skilled labour & 2 & US\$ /man-hour \\
\hline & Unskilled labour & 1 & US\$ /man-hour \\
\hline & Government subsidy & 0 & US\$ \\
\hline \multirow[t]{4}{*}{ Investment } & Cost of land & 500 & US\$ \\
\hline & Cost of storage structure & 600 & US\$ \\
\hline & Cost of biomass mill & 300 & US\$ \\
\hline & Cost of digester\& accessories & 91,700 & US\$ \\
\hline \multirow[t]{4}{*}{ Feedstock } & Manual harvest of straw & 10 & US\$ / tonne \\
\hline & Collection of manure & 2 & US\$ / tonne \\
\hline & Crop residue transport & 10 & US\$ / tonne \\
\hline & Manure transport & 20 & US\$ / tonne \\
\hline \multirow[t]{2}{*}{ Biogas production } & Methane output & 16,700 & $\mathrm{~m}^{3} /$ year \\
\hline & Methane sales & 0.726 & $\mathrm{US} \$ / \mathrm{m}^{3}$ \\
\hline
\end{tabular}


Table 2: Residue availability in Zambrama community

\begin{tabular}{ccccccc}
\hline $\begin{array}{c}\text { Crop } \\
\text { type }\end{array}$ & $\begin{array}{c}\text { Residue } \\
\text { type }\end{array}$ & $\begin{array}{c}\text { Crop amount } \\
\text { harvested } \\
\text { (tonnes) }\end{array}$ & RPR & $\begin{array}{c}\text { Residue } \\
\text { available } \\
\text { (tonnes) }\end{array}$ & $\begin{array}{c}\text { Recoverability } \\
\text { fraction }\end{array}$ & $\begin{array}{c}\text { Net } \\
\text { residue } \\
\text { (tonnes) }\end{array}$ \\
\hline Maize & Straw & 200 & 1.61 & 322 & 0.3 & 96.6 \\
& Husks & 200 & 0.31 & 62 & 0.3 & 18.6 \\
Beans & $\begin{array}{c}\text { Straw }+ \\
\text { pods }\end{array}$ & 16 & 7.99 & 127.84 & 0 & 0 \\
Total & & & & & & $\mathbf{1 1 5 . 2}$ \\
\hline
\end{tabular}

Table 3: Annual socio-economic benefits of project

\begin{tabular}{lll}
\hline Socio-economic indicator & Value & Unit \\
\hline Skilled jobs - investment year & 9,811 & man-hours \\
Unskilled jobs - investment year & 7,866 & man-hours \\
Skilled jobs - annual over 30 year period & 104 & man hours \\
Unskilled jobs - annual over 30 year period & 5,398 & man-hours \\
Biogas available per year & 28,000 & $\mathrm{~m}^{3}$ \\
Amount of firewood displaced per year & 170 & tonnes \\
Time saved from harvesting firewood per year & 3,400 & hours \\
\hline
\end{tabular}

Table 4: Key output variables of the base scenario

\begin{tabular}{lcccc}
\hline \multirow{2}{*}{ Output variable } & \multicolumn{3}{c}{ Project life } & \multirow{2}{*}{ Unit } \\
\cline { 2 - 4 } & 10 years & 20 years & 30 years & \\
\hline NPV & $-86,070$ & $-42,760$ & 21,820 & US\$ \\
IRR & -15 & 6 & 11 & $\%$ \\
Digester size & 300 & 300 & 300 & $\mathrm{~m}^{3}$ \\
Capital cost & 93,110 & 93,110 & 93,110 & US\$ \\
Average revenue per year & 19,370 & 34,800 & 66,630 & US\$ \\
\hline
\end{tabular}

